21 Palmer LB, Greenberg HE, Schiff MJ. Corticosteroid treatment as a risk factor for invasive aspergillosis in patients with lung disease. Thorax 1991;46:15-20.

22 Eliasson O, Hoffman J, Trueb D, Frederick D, McCormick JR. Corticosteroids in COPD. Chest 1986; 89:484-90.

23 Herrmann FR, Safran C, Levkoff SE, Minaker KI Serum albumin level on admission as a predictor of death, length of stay, and readmission. Arch Intern Med 1992;152:125-30.

24 Ingenbleek Y, Carpentier YA. A prognostic inflammatory and nutritional index scoring critically ill patients. Int $\mathcal{F}$
Vitam Nutr Res 1985;55:91-101.

25 Pressac $M$, Vignoli L, Aymard $P$, Ingenbleek $Y$. Usefulness of a prognostic inflammatory and nutritional index in pediatric clinical practice. Clin Chim Acta 1990;188:129-36.

26 Brown RO, Bradley JE, Bekemeyer WB, Luther RW. Effect of albumin supplementation during parenteral nutrition on hospital morbidity. Crit Care Med 1988; 16:1177-82.

27 Delmi M, Rapin C, Bengoa J, Delmas PD, Vasey $H$, Bonjour J. Dietary supplementation in elderly patients with fractured neck of the femur. Lancet 1990;i:1013-6.

\title{
Adventitia
}

\section{The physician as advocate}

"It is painful for me as a physician to admit that a lawyer has saved more lives than I ever will." Mark Taylor, Physicians for a SmokeFree Canada

For pulmonary physicians the current prime candidate for physician advocacy is tobacco. Tobacco kills more Americans every year than alcohol, cocaine, crack, morphine, heroin, automobile accidents, fires, homicide, suicide, and AIDS combined.

Reducing cigarette smoking is one of the most economical ways to prevent death. Even if tobacco consumption is reduced by an education programme which costs money to implement, reducing cigarette smoking in children is a less expensive way to save lives than spending more money on health care or reducing poverty.

The primary care physician interested in the prevention of tobacco induced lung disease can help accomplish this in several ways.

Belong to organised medical groups. Tobacco companies have almost unlimited financial resources. Physicians can only hope to have an impact by working in an organised, cohesive way, and by combining resources. Physicians still have more credibility than any other group in the health care arena.

Role model. Do not smoke or allow smoking in your surgery, and do not, for example, display magazines in the surgery which have cigarette advertisements all over the back page.

Be available as a media spokesperson. The highly paid, highly trained public relations professionals at the Tobacco Institute are continuously available to the media to take advantage of opportunities to get their point across. The physician is still highly respected and needs to be available to reiterate, not only in organised press releases but also in response to queries by the media, that cigarette smoking kills.

Be active in community education. Ninety per cent of tobacco addicts begin smoking before they graduate from high school.

Belong to or support a prohealth organisation. The American Lung Association of the
American Thoracic Society has had an active advocacy role in the prevention of lung disease since the turn of the century and is now a leader in tobacco control activities.

Work for specific legislation. The 1992 Surgeon General's report concluded that "legislation that affects the supply of a demand for tobacco is an effective mechanism for promoting public health goals for the control of tobacco use." A critical national and local focus for legislative activity is to increase excise taxes on tobacco products. This serves the dual purpose of raising revenue for state coffers and reducing smoking. In 1989 the US General Accounting Report estimated that a 21 cent tax increase would result in a reduction of more than 0.5 million teenage smokers. Since people who do not start smoking as adolescents rarely become addicts, the impact of this is especially significant.

Don't be bought out. Dr John Holbrook, a Salt Lake City Professor of Medicine, was approached by a "major tobacco conglomerate" who offered to help him out with his chapter on tobacco for Harrison's Textbook of medicine. The tobacco industry offered him "a substantial amount of money." $\mathrm{He}$ reported that "it was a clear ploy to silence me. He who pays the piper calls the tune. It does influence the way we think."

The American public is waking up to the fact that tobacco causes more preventable death and illness than any other substance. They are concerned about exposure to a toxic carcinogen in the air they breathe. In Canada, attorneys were as important as physicians in the remarkable events leading to the decline in tobacco consumption. As a Canadian Cancer Society lobbyist put it: "Why spend millions on microbiologists and not on lawyers if the lawyers will be more effective in fighting the tobacco epidemic?" Physicians would be wise to recognise their responsibility to serve as advocates.

BARBARA PHILLIPS

[A fuller version of this article will appear in the fournal of Respiratory Diseases.] 